Magdalena Danielewiczowa •

Uniwersytet Warszawski, Warszawa

m.m.danielewicz@uw.edu.pl

\title{
COŚ INNEGO TO COŚ INNEGO NIŻ CO INNEGO. O TYM I RZECZACH PODOBNYCH
}

Słowa klucze: semantyka, polskie zaimki, jednostki operacyjne

Keywords: semantics, Polish pronouns, operational units

W artykule tym chcę skupić uwagę na pewnym polonistycznym szczególe, który na pierwszy rzut oka może się wydać drugorzędny, ale przy bliższym oglądzie inspiruje do zadania pytań dla opisu polszczyzny i, szerzej, dla teorii lingwistycznej istotnych. W nieprzebranej mnogości zjawisk każdego języka naturalnego są takie, które mogą być opisane lub nie i nie będzie to miało większego znaczenia dla kwestii ogólniejszych, są jednak i takie, które nie powinny być zignorowane, bowiem ich analiza wprowadza w sferę rzeczy podstawowych lub przynajmniej niebłahych. Do takich właśnie zjawisk należy, jak sądzę, rozróżnienie, którym chcę się w tym miejscu zająć. Jego wstępną ilustrację niech stanowią pary zdań zawarte w przykładzie (1):

(1) W dyskusji tej chodziło o coś innego. vs. W dyskusji tej chodziło o co innego.

Na rozróżnienie to zwrócił mi uwagę i zachęcił do prześwietlenia ukrywających się za nim problemów profesor Andrzej Bogusławski, który dokonując korekty swej najnowszej książki, stanął w pewnym momencie przed koniecznością wyboru jednej z reprezentowanych w sekwencji (1) form. Wcześniej wzmiankę na temat interesującej mnie tu opozycji zawarł w artykule (Bogusławski 1998) poświęconym bazowemu charakterowi wyrażeń someone 'ktoś' i something 'coś', a na tym tle rosyjskiemu przeciwstawieniu нибудь/-mo. 


\section{Sformułowanie problemu. Materiał ilustracyjny}

Pytanie, jakie nasuwa się $\mathrm{w}$ związku $\mathrm{z}$ podjętym tematem, jest następujące: czy mamy tu mianowicie do czynienia $z$ drobną różnicą formalną, która nie pociąga za sobą żadnych konsekwencji semantycznych, czy też, wręcz przeciwnie, obecność -ś przy zaimku co lub brak wystąpienia tego elementu funduje wyraźną opozycję znaczeniową. Jeśli na pozytywną odpowiedź zasługuje drugi człon zawartej w pytaniu alternatywy, trzeba następnie tę różnicę semantyczną przejaśnić.

$\mathrm{W}$ podstawowych słownikach języka polskiego, bo tylko w tego rodzaju opracowaniach interesujące mnie przeciwstawienie zostało, co prawda zaledwie częściowo, ale jednak odnotowane ${ }^{1}$, konstrukcje analogiczne do przedstawionych w przykładzie (1) opisywane są w kategoriach wariantów tej samej struktury pojęciowej. Do tej kwestii odniosę się szerzej w dalszej części wywodu. Moja hipoteza jest przeciwna. Została ona zasygnalizowana w tytule artykułu. W parze chodzi o co innego i chodzi o coś innego występuje różnica znaczeniowa, która nie powinna być zbywana milczeniem. Stanowisko to wymaga argumentacji opartej na materiale empirycznym.

Gra być może nie byłaby warta świeczki, gdyby przeciwstawienie, o którym mowa, dotyczyło wyłącznie jednego zaimka, nawet tak podstawowego i tak często używanego, jak coś/co w połączeniu z przymiotnikiem inny. Sprawa jest jednak o wiele ogólniejsza i poważniejsza. Zacznijmy od tego, że obok coś innego // co innego mamy całą listę rzeczy podobnych, a więc ktoś inny // kto inny, kiedyś indziej // kiedy indziej, gdzieś indziej // gdzie indziej, dokądś indziej // dokąd indziej, skądś indziej // skąd indziej // skądinąd, którędyś indziej // którędy indziej. Oprócz tego są jeszcze pary form czyjś inny // czyj inny, jakiś inny // jaki inny i któryś inny // który inny. Dwie ostatnie wymagają dodatkowego komentarza, ponieważ poza interesującą nas tu opozycją semantyczną wprowadzają także zróżnicowanie pragmatyczne. Rozwinę tę myśl na odpowiednich przykładach w dalszej części artykułu. Na razie przywołajmy z Narodowego Korpusu Języka Polskiego materiał ilustrujący użycie odpowiednich zaimków w kilku nieproblematycznych, jak sądzę, parach:

(2) Znak [...] zawsze odsyła naszą myśl ku czemuś innemu niż to, co jest pod ręką.

(3) Dla każdego co innego najważniejsze.

(4) Pożyczyłeś mi tylko te dwa kryminały. Tamten musiałeś dać komuś innemu.

(5) Smutek uciskał mu serce w chwili, kiedy spostrzegał, że tańcząc z kim innym, była wesoła i rozbawiona.

(6) Wiadomo, [dziecko] było bardzo chore, to mówiliśmy, że na spacer pójdzie jutro, pojutrze, może kiedyś indziej.

1 Omawiane tu kwestie zostały pominięte np. w typologicznym opracowaniu zaimków nieokreślonych Martina Haspelmatha (1997). Nie uwzględniła ich także w swej polonistycznej monografii Elżbieta Wierzbicka-Piotrowska (2011). 
(7) Poczuł lekki ból brzucha, który kiedy indziej wziąłby za sygnał sytości, ale dziś [...] wydał mu się on jakimś nieokreślonym bodźcem.

(8) Sądzisz, że w takim stanie mogę pojechać $g d z i e s ́$ indziej niż na pasaż?

(9) Prawdziwe życie toczyło się gdzie indziej, daleko poza betonowymi murami.

(10) A jak nam zamkną Redakcję, to pójdziemy dokądś indziej.

(11) Każdy ptak leci dokąd indziej, my nie możemy odlecieć.

(12) Spełniam też wymogi w zakresie wieku i wykształcenia - i pokazuje dyplom jakiegoś technikum afgańskiego czy skądś indziej, z innej egzotycznej części świata.

(13) Muzyka znów zdaje się dochodzić skąd indziej.

(14) - Jaki mąż! [...] Mąż to on jest, ale czyjś inny.

(15) Ofiarować samego siebie: [...] prawdziwie ciało własne, krew swoją, ból swój, nie czyj inny...

(16) Zdumiewającym zbiegiem okoliczności tym samym szlakiem szedł w przeciwną stronę Miki z Koszyc albo któryś inny znajomek z plecakiem takim jak mój, lecz pustym.

(17) Mało która inna [gra] daje grającym tak wiele możliwości.

(18) Nie studiował u nas medycyny, lecz jakiś inny kierunek.

(19) Nie weźmiesz ty, weźmie jaki inny człowiek, niedobry, nieszlachetny, wyrachowany.

Nie wszystkie interesujące mnie formy reprezentowane są w NKJP równie często: tylko parę potwierdzeń ma np. kiedyś indziej, dokądś indziej, zaledwie jedno dokąd indziej i skądś indziej, natomiast odkąd indziej, którędy indziej czy którędyś indziej w ogóle nie zostały odnotowane, choć przykłady ich użycia z łatwością można znaleźć w Internecie:

(20) Może wracał którędyś indziej, skoro nie znaleziono go na tej trasie.

(21) Czy wędrówki ludów do Europy szły tylko przez naszą ziemię czy również którędy indziej?

lub w razie potrzeby utworzyć.

\section{Brak wymienności zaimków $z$ finalnym -ś i bez niego}

Podane wyżej przykłady są wyraziste, ale do umocowania przedstawionej hipotezy nie wystarczą. Pokazują one bowiem jedynie to, że Polacy w pewnych sytuacjach używają jednej, a w innych znów drugiej z interesujących nas form. Wciąż jednak nie widać, dlaczego stosowne wyrażenia miałyby nie być wariantywnymi wykładnikami odpowiednio tych samych pojęć. Takiej konkluzji zdaje się sprzyjać fakt, że 
właściwie we wszystkich zaprezentowanych przed chwilą kontekstach wchodzące w grę formy mogłyby być zastosowane wymiennie bez niebezpieczeństwa wykroczenia poza semantyczną normę języka polskiego. Przy tego rodzaju podstawieniach różnice znaczeniowe albo w ogóle by się nie ujawniły, albo byłyby tak subtelne, że nawet dla wrażliwego ucha nieuchwytne. Po raz kolejny okazuje się, że korpusy językowe są bardzo pożytecznym narzędziem współczesnej lingwistyki, ale tego, co najważniejsze, w nich nie znajdziemy. Kluczowe przykłady diagnostyczne muszą być zaprojektowane na własną rękę. W odniesieniu do bardzo subtelnych zjawisk, do jakich należy rozróżnienie stanowiące przedmiot prowadzonych tu rozważań, nie jest to bynajmniej łatwe. Spróbujmy jednak zaryzykować i przedstawić takie wypowiedzenia, w których kto/ktoś, co/coś, kiedy/kiedyś, gdzie/gdzieś itd. nie są wzajemnie podstawialne. Oto parę przykładów tego rodzaju:

(22) Karol w tym wyścigu się nie liczy, Tadzio - to co innego // * coś innego.

(23) Rodzinnego domu nie sprzedam za nic. Ani teraz, ani kiedy indziej // *kiedyś indziej.

(24) Wiem na pewno, że w ciągu ostatnich dni był w dwóch miejscach: w Atenach i jeszcze gdzieś indziej // * gdzie indziej. Musisz ustalić gdzie.

(25) Wyłoniono trzech kandydatów na dyrektora naszego instytutu. My chcemy Kowalskiego, ale dyrektorem i tak zostanie któryś inny // ^który inny spośród wyłonionej trójki.

(26) Widziałem tych, co to zrobili. To był Nowak i jeszcze ktoś inny // *kto inny.

(27) Okazało się, że ten w szpitalu to jakiś inny // *jaki inny Stanisław Madej.

Kontekst (22) domaga się komentarza. Opierając się na glosach zawartych w niektórych słownikach języka polskiego, można by sądzić, że występujące w nim co innego ma charakter idiomatyczny $\mathrm{i}$, jako takie, nie może być utożsamiane $\mathrm{z}$ homonimicznym względem niego wyrażeniem reprezentowanym w przykładach (1) i (3); że zatem nasz test jest chybiony i nie spełnia pokładanych w nim nadziei. Jeśli bowiem mamy do czynienia ze związkiem frazeologicznym, to nie należy się dziwić, że jego naruszenie, choćby i niewielkie, prowadzi do anomalii. Tego rodzaju zastrzeżenie zgłosiłby z pewnością autor hasła zamieszczonego w ISJP (I: 538), który postuluje wręcz istnienie dwóch różnych związków frazeologicznych z kształtem co innego. Przywołam tę z owych dwóch zawartych w ISJP charakterystyk, która jest w tym miejscu relewantna:

Wyrażenia co innego używamy w odniesieniu do rzeczy, osób, sytuacji itp., które chcemy przeciwstawić czemuś. Ja to co innego, mnie wolno... Czym innym jest przepisywanie z maszynopisu, a czym innym z rękopisu.

Problem w tym, że co innego, o które chodzi w moim artykule, podobnie zresztą jak coś innego, używane jest właśnie w celu przeciwstawienia sobie różnych 
rzeczy. Zaproponowana w ISJP definicja nie tłumaczy więc konieczności mnożenia znaczeń interesującego nas wyrażenia. Znaczące jest również to, że w przykładowym materiale ilustracyjnym co i czym można by spokojnie wymienić na coś i, odpowiednio, czymś.

W WSJP PAN co innego takie, jak zastosowane w przykładzie (22), również uznane zostało za odrębną jednostkę leksykalną i, co więcej, zaliczone do komentarzy metatekstowych. Definicja, którą przypisano temu wyrażeniu, ma postać następującą: 'o tym, o czym mowa teraz, nie można powiedzieć tego samego, co zostało powiedziane o czymś innym'. Glosę tę autor hasła starał się wynieść na poziom mówienia o mówieniu, ale ten zabieg niestety się nie udał: wbrew zamierzeniu obejmuje ona zarówno konteksty typu (22), jak i (1), (3). I tak powinno być, ponieważ, jak chcę twierdzić, użyte w nich jest to samo jednoznaczne wyrażenie, tyle tylko, że odniesione do różnych obiektów pełniących funkcję tematu wypowiedzi, a mianowicie raz do fragmentów świata zewnętrznego, raz do zrealizowanych uprzednio wypowiedzi, co jednak jeszcze nie wystarcza, by uczynić z co innego metakomentarz. W zdaniu (22) nie może być mowy o metatekście, komentarze metatekstowe nie przyjmują bowiem na siebie głównego akcentu zdaniowego, zawsze są stematyzowane, co wiąże się z niemożnością ich zanegowania, a tu właśnie co innego ma charakter rematyczny (por. nie co innego $<n i \dot{z} . . .>$ ). Na marginesie powiem, że całkiem inną decyzję należy podjąć w odniesieniu do formy skądinąd, homofonicznej w stosunku do tej, która wpisuje się w interesujący mnie szereg. To rzeczywiście jest inherentnie tematyczny komentarz metatekstowy. (Por. dwa równokształtne, ale różnoznaczne skądinąd w zdaniu: Cyganie, wywodzacy się skądinąd z Indii, musieli przywędrować do nas skądinąd; pierwsze z nich ma charakter metatekstowy). Szczegółowe kryteria przynależności danego elementu języka do metapoziomu starałam się przedstawić w pracach: Danielewiczowa 2007, 2012: 81-92².

2 Jeden z Recenzentów tego artykułu uznał, że przedstawione argumenty nie są wystarczające, by zakwestionować istnienie w polszczyźnie odrębnej jednostki o kształcie: $X<$ to $>$ co innego // co innego $X \mathrm{z}$ ustalonym porządkiem linearnym i określoną intonacją. Kwestię tę pozostawiam otwartą i dla siebie samej, i dla Czytelnika. Być może rzeczywiście kluczową rolę będą tu odgrywały względy prozodyczne. Istnienie bądź nieistnienie odpowiedniej jednostki nie ma zasadniczego znaczenia dla głównych tez mojego opracowania. Jeśliby przykład (22) wydał się komuś nieodpowiedni, bo z nim związana jest kontrowersja, można z łatwością wymienić go na bardziej przekonujący, np.: Budynki, o których mowa, to dom, młyn i coś innego. Zgadnij co. vs. ${ }^{\star} B u d y n k i$, o których mowa, to dom, mtyn i co innego. Zgadnij co.

W tej samej recenzji zakwestionowane zostało moje twierdzenie, że wyrażenia metatekstowe nie przyjmują na siebie akcentu zdaniowego i, co za tym idzie, zawsze są stematyzowane. Twierdzenie to podtrzymuję. Brak tu miejsca na rozwinięcie komentowanej kwestii. Powiem tylko, że niezdolność do przyjęcia na siebie akcentu zdaniowego jest rzeczą wtórną w stosunku do nienegowalności danego komponentu wypowiedzenia. Partykuły, bo o tej kategorii wyrażeń wspomina Recenzent, podobnie jak inne komentarze metatekstowe, generalnie nie podlegają przeczeniu. $\mathrm{Na}$ temat ewentualnych wątpliwości związanych z wyrażeniem tylko (a także wyłącznie i jedynie) zob. Bogusławski 2013. Tzw. dopowiedzenia nie są moim zdaniem odrębną klasą części 


\section{Pytanie o status segmentów inny i indziej}

Zanim podejmę próbę wskazania źródła anomalii ujawnionych w przykładach (22)(27), a co za tym idzie: przejaśnienia interesującej mnie tu opozycji znaczeniowej, chciałabym jeszcze zwrócić uwagę na pewien teoretyczny problem wyłaniający się z przedstawionego do tej pory materiału językowego. Chodzi mianowicie o status wyrażeń inny i indziej przy odpowiednich formach. Nie jest to bynajmniej problem banalny, a wiąże się on z podstawową dla opisu języka kwestią delimitacji potoku mowy na jednostki leksykalne i operacyjne służące do konstruowania wypowiedzi. Segment inny przypomina przymiotnik, który występuje np. w połączeniu inny kolega czy nikt inny, sprawia więc wrażenie samodzielnego. Takie wrażenie musieli też odnieść autorzy odpowiednich haseł w podstawowych słownikach języka polskiego, ponieważ wystąpienia inny w kontekście interesujących mnie zaimków nie zostały w nich jako coś szczególnego i zasługującego na uwagę odnotowane. Z kolei ciągi indziej i niekiedy inąd leksykalnej niezależności ewidentnie nie wykazują (choć zalecenia ortograficzne są w stosunku do nich, co trudno notabene zrozumieć, różne). W związku z tym w opracowaniach leksykograficznych praktykowane jest $\mathrm{z}$ reguły rejestrowanie, na prawach całostek słownikowych, ich możliwych połączeń. Za formy zleksykalizowane uznała takie połączenia również Urszula Andrejewicz (1989), a w ślad za nią Magdalena Żabowska (2017), co moim zdaniem zaważyło na stopniu ogólności ciekawego skądinąd artykułu drugiej z wymienionych autorek, poświęconego w gruncie rzeczy dokładnie tej samej opozycji, która i mnie interesuje. Do pracy M. Żabowskiej odniosę się szerzej za chwilę. Formy z dodatkiem inny oraz indziej traktowane są w różnych opisach gramatyki polskiej jako odrębna kategoria leksemów zaimkowych ${ }^{3}$. Zwraca przy tym uwagę to, że lista takich dwuczłonowych zaimków nie jest $\mathrm{z}$ reguły $\mathrm{w}$ poszczególnych opracowaniach wyczerpywana. Dla przykładu w ISJP (I: 535) i WSJP PAN zapomniano o wyrażeniach kiedyś indziej, nigdy indziej, skąd indziej, skądś indziej, skądkolwiek indziej, znikąd indziej, dokąd indziej, dokądś indziej, dokądkolwiek indziej, donikąd indziej, odkąd indziej, odkądkolwiek indziej, którędy/którędyś indziej, którędykolwiek indziej. Te opuszczenia wydają się bardzo znaczące. Do relewantnych charakterystyk w WSJP PAN nie będę się odnosić, ponieważ są one moim zdaniem nieudane, głównie ze względu na nieuzasadnione mnożenie znaczeń. Jeśli zaś chodzi o komentarze odniesione do hasła in$d z i e j$ w ISJP, to wyglądają one tak, jakby ich autor zdawał sobie sprawę, że opisywany

mowy. Zjawisko to ma charakter czysto tekstowy i, jako takie, rządzi się swoistymi prawami. Jest rzeczą jasną, że jeśli na zadane pytanie odpowiem krótko: być może lub na pewno to partykuły te

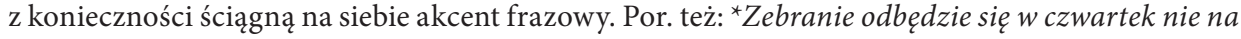
pewno. vs. - Czy zebranie odbędzie się w czwartek? - Nie na pewno.

3 Na przykład Maria Zagórska Brooks (1975: 312) określa je mianem zaimków porównawczych (comparative pronouns). Irena Szczepankowska (2012: 283) z kolei ustanawia dla nich odrębną klasę zaimków wskazujących przeczacych. 
człon odnosi się do całej serii słów, ale po pierwsze, nie starczyło mu cierpliwości, żeby zbadać ją dokładnie, a po drugie, nie bardzo wiedział, co z tą serią dalej począć, jakiego mianowicie dostarczyć uogólnienia. Cytuję odpowiednie glosy in extenso: 1. Wyrażeń gdzie indziej, gdzieś indziej, gdziekolwiek indziej, nigdzie indziej i wszędzie indziej używamy tak jak zaimków "gdzie”, „gdzieś”, „gdziekolwiek”, "nigdzie”, „wszędzie”, mając na myśli miejsce inne niż to, o którym mowa.

2. Wyrażeń kiedy indziej, kiedykolwiek indziej używamy tak jak zaimków „kiedy”, „kiedykolwiek”, mając na myśli czas inny niż ten, o którym mowa.

Jakiego rodzaju mogłoby to być uogólnienie? Nie będę w tym miejscu wchodziła w szczegóły, bo jak się za chwilę okaże, nie jest to ze względu na cel mojego opracowania sprawa centralna, powiem tylko, że indziej (oboczne w nielicznych, regulowanych względami fonetycznymi wypadkach $\mathrm{z}$ inq̨), stowarzyszone $\mathrm{z}-s$ lub brakiem tej cechy, mogłoby być potraktowane jako segmentalny wykładnik pewnej operacji w sensie nadanym temu terminowi przez A. Bogusławskiego (1978). Byłaby to więc jednostka przynależąca raczej do komponentu gramatycznego niż leksykalnego współczesnej polszczyzny. Takiemu rozstrzygnięciu sprzyja zarówno klarownie wyodrębniająca się klasa operandów tej hipotetycznej jednostki, jak również jej produktów, możliwych do określenia w sposób zgeneralizowany. Jeśli chodzi o segment inny, to sprawa jest bardziej złożona. Z jednej strony zdaje się on przy ktoś i coś wymieniać w układach proporcjonalnych z różnorodnymi, dobrymi przymiotnikami, np. coś innego tak jak coś dobrego, miłego, strasznego, głupiego; ktoś inny jak ktoś wesoły, odpowiedzialny, szczery, niegodziwy, wyższy od innych, co mogłoby potwierdzać jego samodzielny, czysto leksykalny charakter, z drugiej zaś - z formami ktośl kto, coś/co, któryślktóry, jakiśljaki tworzy konkatenacje w pewien sposób analogiczne względem konstrukcji z członem indziej/inąd. Co ciekawe, tego samego nie można natomiast powiedzieć o parach jakoś inaczej // jak inaczej, dlaczegoś inaczej // dlaczego inaczej, czemuś inaczej // czemu inaczej, ileś innych // ile innych. Ten fakt bynajmniej nie dziwi, przeciwnie, zdaje się po raz kolejny potwierdzać, że wyrażenia jak, dlaczego/czemu i ile mają nieco inne własności niż pozostałe pytajniki ${ }^{4}$.

\section{Rozszerzenie pola badań o konteksty modalne}

Wróćmy jednak do zasadniczego wątku tego artykułu. Przy bliższym oglądzie okazuje się, że przedstawiona do tej pory kategoria wyrażeń z segmentami inny, indziej/ inąd nie jest jedynym kontekstem, w jakim ujawnia się interesująca nas opozycja. Wystarczy porównać w parach następujące przykłady:

4 Na odmienność tych właśnie zaimków zwróciła też uwagę w przywoływanym już artykule M. Żabowska (2017). 
(28) Dałbyś się może napić czegoś mocniejszego. vs. Dałbyś się może napić czego mocniejszego.

(29) Potrzeba mi kogoś do pomocy. vs. Potrzeba mi kogo do pomocy.

(30) Czy ktoś widział coś podobnego? vs. Czy kto widział co podobnego?

(31) Komu ona kiedyś w czymś pomogła? vs. Komu ona kiedy w czym pomogła?

(32) No, dobrze, ale czy można gdzieś te maski kupić? vs. No, dobrze, ale czy można gdzie te maski kupić?

(33) Zachował się jak jakiś idiota. vs. Zachował się jak jaki idiota.

(34) Podaj no któryś tę laskę! vs. Podaj no który tę laskę!

Każde drugie ze zdań w kontekstach (28)-(34) jest dodatkowo w taki sam sposób nacechowane pragmatycznie. Nosi na sobie mianowicie piętno dawności, a co za tym idzie literackości. Zabieg pominięcia -ś przy zaimku w odpowiednim dlań kontekście stosowany jest bowiem często $\mathrm{w}$ celach stylizacyjnych z myślą o archaizacji lub stylizacji gwarowej tekstu. Niezależnie jednak od wskazanej różnicy pragmatycznej w przykładach (28)-(34) występuje przede wszystkim interesująca nas opozycja semantyczna. Nie bez znaczenia jest to, że jeśli zabraknie dodatkowego wykładnika w postaci inny, indziej, to najchętniej ujawnia się ona w pytaniach, często stawianych retorycznie, w zdaniach warunkowych, rozkazujących i życzących lub porównawczych. Umieszczenie akcentowanego zaimka pozbawionego -ś w kontekstach oznajmujących przekształca je $\mathrm{w}$ struktury pytajne $\mathrm{z}$ silnie topikalizowanym elementem datum quaestionis (oznaczam tę topikalizację za pomocą symbolu $\lambda$, a akcent rematyczny sygnalizuję pogrubieniem):

\section{(35) A ona $\lambda$ komu pomogła?}

Szczegółową typologię kontekstów modalnych, w których oponują ze sobą zaimki z -ś i bez niego, sporządziła w swym artykule M. Żabowska (2017). Autorka postawiła tezę, z którą się $\mathrm{w}$ pełni utożsamiam, że opozycja ta ma charakter nie tylko pragmatyczny (w odniesieniu do form bez -ś Żabowska mówi notabene o potoczności, co z kolei nie wydaje mi się trafne), lecz także semantyczny. Sprawdziwszy uprzednio takie wchodzące w grę parametry, jak: wyznaczanie - brak wyznaczania, wiedza - niewiedza, kwestia wolnego wyboru, badaczka konkluduje, że seria pozbawiona -ś po pierwsze, podporządkowana jest generalizacji, a nie konkretyzacji, a po drugie, służy charakteryzowaniu, a nie wskazywaniu obiektów. Argumenty językowe, podtrzymujące tezę główną i obserwacje cząstkowe, mają w omawianym artykule różną wagę; obok przykładów słabszych, a także, w moim przekonaniu, niesłusznie opatrzonych dyskwalifikującą gwiazdką ${ }^{5}$, znalazły się też testy bardzo

5 Na taką dyskwalifikację nie zasługują, zgodnie z moją kompetencją językową, zdania: (26') Kogo nie zaproszę, ten mi odmawia; Kogo bym nie zaprosił, ten mi odmawia/odmówit, (26”) Pójdę<wszę- 
ciekawe i przekonujące, choć - jak sądzę - nie ze wszystkich zrobiła M. Żabowska taki użytek, na jaki zasługują.

Komentowane opracowanie ma jednak poza wskazanymi zaletami również wady. Zawiera ono mianowicie tezy fałszywe, będące konsekwencją nieuprawnionego uogólnienia, dokonanego na niepełnym materiale, z pominięciem kontekstów analogicznych do wypowiedzeń (1)-(21), w których odpowiednim zaimkom towarzyszą segmenty inny i indziej. A to właśnie te konteksty należy uznać za podstawowe, po pierwsze dlatego, że w przeciwieństwie do konstrukcji modalnych należą do wyrażeń bazowych, w terminologii A. Bogusławskiego ${ }^{6}$ - do kontradyktorycznych werdyktów obiektywizujących, a po drugie dlatego, że interesująca nas opozycja nie jest w nich, poza nielicznymi wyjątkami, zaburzona efektami stylistycznymi. O kształcie inny M. Żabowska w ogóle nie wspomina, natomiast indziej uznaje w przypisie 3. na s. 239 za niesamodzielny człon form w pełni zleksykalizowanych. Jeśli te zignorowane przez autorkę konteksty uwzględnić, to okazuje się nieprawdą, że: a) zaobserwowane przeciwstawienie dotyczy wyłącznie kontekstów modalnych; b) seria bez -ś nie może wystąpić w zdaniach oznajmujących; c) zaimki pozbawione -ś występują jedynie w kontekstach niefaktywnych (jak może nie całkiem zgodnie z tradycją określa je Żabowska), to jest w odniesieniu do zdarzeń quasi-rzeczywistych. Dodajmy, że zakwestionowanie twierdzenia zawartego w punkcie b) unieważnia też główny dystrybucyjny argument autorki, przemawiający za koniecznością semantycznego odróżnienia ktoś od kto, coś od co, gdzieś od gdzie itd. Kontekstów diagnostycznych trzeba szukać nie gdzie indziej, jak właśnie w pewnych zdaniach oznajmujących, a mianowicie $\mathrm{w}$ tych, w których zakazana jest wymienność członów interesującej nas opozycji. Takich kontekstów starałam się dostarczyć w przykładach (22)-(27). Świadczą one moim zdaniem dobitnie o niepokrywaniu się zakresów stosowalności serii $\mathrm{z}$-ś i bez niego. Z kolei ów brak identyczności w dystrybucji tych serii stanowi poważny argument na rzecz istnienia odpowiedniej różnicy semantycznej.

\section{Rozważana opozycja i kwestia wyznaczania}

Podobnie jak M. Żabowska, uważam, że istotą interesującego nas przeciwstawienia jest wyznaczoność, którą zapewniają zaimki z -ś, i brak wyznaczania w wypadku użycia ich kontrpartnerów bez -ś. Jeśli zaś chodzi o drugą ze wskazanych przez autorkę par cech, to znaczy o konkretyzację przeciwstawioną generalizacji, to stanowi

dzie> tam, gdziekolwiek ty pójdziesz, (28) Chciałabym, żeby kto kiedy kogo pokochał, na przykład z kontynuacja w tym świecie bez miłości.

6 Stratyfikacji zjawisk mownych i miejscu kontradyktorycznych werdyktów oceniających pośród tych zjawisk poświęcona jest w całości książka A. Bogusławskiego Lingwistyczna teoria mowy. Preliminaria (Bogusławski 2021). 
ona w stosunku do kwestii wyznaczania efekt wtórny i całkowicie od tej podstawowej sprawy zależny.

Paradoksalne wydaje się to, że zaimki powszechnie nazywane nieokreślonymi, a więc te zakończone na -ś, w rozważanych tu kontekstach, wbrew temu, co na ten temat pisze Stanisław Karolak (EJO: 604) i z czym z kolei słusznie polemizuje I. Szczepankowska (2012: 278, 286), właśnie wyznaczają odpowiednie obiekty, niezależnie od tego, że nadawca może ukrywać przed odbiorcą, o jakie konkretnie obiekty chodzi, a bywa, że i on sam ma o ich własnościach mgliste pojęcie 7 . Użyciu wyrażeń z serii zakończonej na -ś towarzyszy jednak zawsze przesądzenie istnienia określonej osoby, przedmiotu, miejsca czy odcinka na osi czasu. Wykładnik ten ma, co więcej, takie znaczenie, jak subskrypt w językach sformalizowanych: indywidualizuje i wyodrębnia, przede wszystkim czysto mentalnie, dany obiekt w rzeczywistości pozajęzykowej. Dlatego m.in. zdanie (23) z użyciem kiedyś jest nieakceptowalne. Wprowadza ono sprzeczne informacje: na poziomie presupozycji jest tu mianowicie powiedziane, że istnieje taki moment, w którym wiadomy dom rodzinny mógłby być sprzedany, natomiast na poziomie asercji tej samej porcji sensu się przeczy. O tym, że zaimki zakończone na -ś zaangażowane są w wyznaczanie osób i przedmiotów, wymownie świadczy przykład (27). W zdaniu tym, w którym mowa o osobie wskazanej już uprzednio za pomocą innych środków, użycie niewyznaczającego jaki prowadzi do sprzeczności. Nie znaczy to notabene, że konkatenacje odpowiednich zaimków bez -ś z imionami własnymi są absolutnie zabronione, mogą się one jednak pojawiać wyłącznie w kontekstach niewyznaczonych, np.:

(36) Dajcie mi tu jakiego Nowaka! Albo Kowalskiego, jeśli Nowaków nie ma.

przy założeniu, że chodzi o dowolną osobę noszącą nazwisko Nowak.

Zaimki z finalnym -ś w interesujących mnie zastosowaniach współczesnych nieoczekiwanie aktualizują historyczne, dawno zapomniane znaczenia tej wygłosowej cząstki. W świetle egzystencjalnego założenia, o którym była mowa przed chwilą, niezmiernie ciekawa wydaje się glosa dotycząca cząstki -si zawarta w czeskim słowniku etymologicznym Jiř́iego Rejzka (2015: 628). Autor twierdzi, że prasłowiańskie $s i$ wykładane jest zwykle jako 2. os. l.p. dawnego optativu tworzonego od rdzenia ${ }^{{ }^{\prime}} h_{1}$ es 'być', zachowanego m.in. w postaci łac. sis. Tak więc np. czeskie formy kdosi 'ktoś, cosi 'coś' miałyby zdaniem autora znaczyć pierwotnie w przybliżeniu 'niechbyś był, kim/czym chcesz'. Z kolei Witold Mańczak (2017: 175) wywodzi znaczenie interesującego nas -ś przy polskich zaimkach od prasłowiańskiego zaimka wskazującego sjb, który w staropolszczyźnie, po zaniku jerów, przybrał postaci rodzajowe si, sia, sięl

7 Pouczające informacje na temat rozumienia w literaturze przedmiotu terminów wyznaczoność niewyznaczoność, określoność - nieokreśloność zawarła w swej książce E. Wierzbicka-Piotrowska (2011: 27-34). 
sio, a do dzisiaj zachował się jedynie w paru utartych wyrażeniach: ni to, ni sio; a to, a sio; do siego roku, a także w formach latoś (skrót od latosie) 'tego roku' i dziś 'tego dnia' (por. też np. ukraińskie днесь czy ros. здесь).

Na marginesie zaznaczę, że wbrew pozorom zaimki z członem -kolwiek również mają w pewnym sensie charakter wyznaczony ${ }^{8}$. Wyznaczoność dotyczy tu jednak, jak sądzę, nie tyle poszczególnych obiektów, ile ich zbiorów, które mogą być albo wskazane eksplicytnie, np. Wezmę którykolwiek z tych ołówków, Wszystko, cokolwiek wtedy powiedziat, było fałszem, albo rekonstruowane przez odbiorcę po uwzględnieniu przez tegoż treści stałej lingwistycznej ' 'wiesz, o czym mówię', np. Postaw te paczkę gdziekolwiek [tzn. np. 'w dowolnym miejscu przestrzeni, w której się aktualnie znajdujemy']. Zauważmy, że formy, w których cecha -ś poprzedza segment -kolwiek, a więc ktośkolwiek, cośkolwiek, gdzieśkolwiek, jakiśkolwiek, choć rzadkie, pozostają w użyciu, a współwystępowanie interesujących nas wykładników nie tworzy efektu sprzeczności; jeśli budzą one wątpliwość, to raczej ze względu na wrażenie lekkiej pleonastyczności. Warto też w tym miejscu zaznaczyć, że w przeciwieństwie do -kolwiek cząstka bądź w układach co bądź, kto bądź, gdzie bądź, jaki bądź itp. podkreśla właśnie brak wyznaczania. Zgodnie z przewidywaniem łączy się więc ona jedynie z zaimkami pozbawionymi -ś. Konstrukcje w rodzaju *coś bądź, ${ }^{\star} j a k i s ́$ bądź, ${ }^{\star} k i e d y s ́ b a q d z ́$ są nieakceptowalne. Na temat funkcji tej cząstki por. Wierzbicka-Piotrowska 2011: 166-168.

Wracając do rozważanej tu opozycji semantycznej, trzeba powiedzieć, że jej opis w terminach: wyznaczoność - brak wyznaczoności ma charakter w dużej mierze techniczny. Kryteria użyć niewyznaczonych (non-specific) wskazane przez Haspelmatha (1997) nie sprawdzają się w odniesieniu do interesującego nas materiału polskiego. Na przykład w zdaniu drugim z przykładu (34) trudno jest zaprzeczyć istnieniu takiego kogoś, kto miałby nadawcy podać laskę. Gdyby taka negatywnie egzystencjalna presupozycja wchodziła w grę, wypowiedzenie to, jako wewnętrznie sprzeczne, traciłoby sens. Również w pytaniach stawianych retorycznie, podobnych do (30), (31), wbrew obiegowym interpretacjom nie mamy do czynienia z negacją ich założeń. Wystarczy tu przypomnieć zastosowany przez A. Bogusławskiego (1973) chwyt polegający na możliwości kontynuowania tego rodzaju pytań za pomocą zdań, które falsyfikują zasadność sprowadzania retoryczności do zaprzeczenia datum quaestionis: Czy on co z tego zrozumiat? Obawiam się, że niewiele. obok Absolutnie nic. Przesądzenie istnienia danej osoby lub obiektu jest nieodłączne od użycia zaimków zakończonych na -ś, ale nierelewantne dla serii bez -ś. Trzeba więc szukać innego sposobu przejaśnienia interesującej nas różnicy. Trudność polega na tym, że jeśli chodzi o ktoś/kto, coślco, bo na dobrą sprawę do tych dwóch rzeczy można

8 Zaimki z serii -kolwiek są notabene w wielu kontekstach wymienne z tymi zakończonymi na -ś (por. Haspelmath 1997), choć rację ma M. Żabowska, że nie może być mowy o ich równoznaczności. 
zredukować pozostałe wchodzące $\mathrm{w}$ grę pary zaimków ${ }^{10}$, to pozostajemy w sferze zjawisk niedefiniowalnych, dotykamy więc w pewnym sensie granicy języka. $\mathrm{Z}$ tego powodu skazani jesteśmy jedynie na przybliżenia dokonywane w naukowym, a więc do pewnego stopnia technicznym metajęzyku.

Jakiego rodzaju przybliżenie można by zaproponować? Omawiana w tym artykule opozycja sprowadza się, najkrócej mówiąc, do kluczowego w języku przeciwstawienia tego, o czym się mówi, temu, co się mówi. Zaimki zakończone na -ś to indeksy w ścisłym tego słowa znaczeniu. Działają tak, jak Wittgensteinowskie czułki, które w zdaniu służą do tego, by dotykać osób i obiektów, czyli „przedmiotów prostych”, składających się na „substancję świata”, i te przedmioty reprezentować. Zapewniają korelację języka i świata, to mianowicie, że użyte zdanie staje się obrazem odpowiadającej mu rzeczywistości ${ }^{11}$. Do wyrażeń tego typu nijak nie pasuje nazwa pronomina, ponieważ „nie zastępują” one żadnych nominalnych bytów językowych. Trafniej charakteryzowałaby ich miejsce w języku nazwa prosubiecta/proobiecta, jako że stają za osoby i rzeczy. Jeśli chodzi natomiast o zaimki z serii pozbawionej -ś, to markują one jedynie pozycje argumentowe przy odpowiednich predykatach. Pozycje te nie są zaktualizowane. Szczególnie wyraźnie widać to w wypowiedzeniach oznajmujących, w których zaimkowi towarzyszy człon inny/indziej. Tego rodzaju formy mają rzeczywiście charakter pronominalny: wchodzą na miejsce takich predykatywnych struktur, jak: inna osoba, inny przedmiot, inny moment czasowy, inne miejsce w przestrzeni, inna droga itd.; niczego nie wskazują, do niczego nie odsyłają, przywołują jedynie w sposób ogólnikowy odpowiednie predykatywne kontrasty. Zaimki z finalnym -ś również mogą być użyte kontrastywnie, ale przedmioty, do których odsyłają, przeciwstawiane są w takiej sytuacji nie własnościom, lecz innym przedmiotom. Zauważmy, że pierwszy człon tytułu mojego opracowania mógłby równie dobrze mieć postać następującą: „Coś innego to co innego niż co innego”. Punkt ciężkości byłby wtedy jednak przesunięty z przeciwstawienia konkretnych obiektów: 'to oto wyrażenie coś innego nie jest tożsame $\mathrm{z}$ tym ${ }_{2}$ oto wyrażeniem co innego' na kontrast o charakterze kategorialnym 'wyrażenie coś innego należy do innej kategorii, ma inne własności niż wyrażenie co innego'. Kiedy mówię, że zależało mi na czymś innym, to mam na myśli konkretny obiekt różny od wiadomego; kiedy zaś powiem, że zależało mi na czym innym, to koncentruję uwagę na tym, że myślałam o obiekcie, któremu przysługują cechy odmienne od wiadomych. Konstrukcje dewiacyjne powstają, gdy - jak w przykładach (22)-(27) - tego rodzaju przesunięcie, w jedną bądź drugą stronę, jest semantycznie zablokowane: w grę wchodzi bowiem jedynie myślenie o kontraście indywiduów, por. (24)-(27), lub o kontraście cech, jak w wypadku (22)-(23).

10 Gdzieś to miejsce w przestrzeni, a więc coś, podobnie którędyś. Kiedyś odsyła do punktu na osi czasu, a więc znowu do czegoś, czyjś to relacja między kimś a czymś lub kimś a kimś innym.

11 Mam tu na myśli Tractatus logico-philosophicus, a w szczególności tezy 2.115-2.1515. Zob. Wittgenstein 2006. 


\section{Językowy status opozycji -ś : Ø}

W ostatnim punkcie swojej wypowiedzi chciałabym postawić pytanie o miejsce w języku owego towarzyszącego zaimkom -ś, a ściślej biorąc: opozycji -ś do braku tego elementu. Interesujący mnie wykładnik traktowany bywa $\mathrm{z}$ reguły jako postfiks. W ten sam sposób kwalifikuje się notabene również segment -kolwiek. Nie bardzo ma to sens wobec faktu, że zgodnie z ogólnie przyjętą definicją postfiksy mają być morfemami usytuowanymi w wyrazie po końcówce fleksyjnej, a tymczasem tylko nieliczne spośród zaimków, którym może towarzyszyć -ś lub -kolwiek (albo jedno i drugie jednocześnie), są odmienne. Można zresztą nazywać te segmenty dowolnie, to wydaje się najmniej istotne, ważne jest natomiast ustalenie ich funkcji i przynależności do odpowiedniego podsystemu języka. Pierwszej sprawie w od-

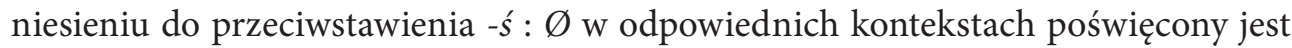
w całości ten artykuł, druga kwestia pozostaje otwarta. Moja hipoteza współgra z tą sformułowaną w punkcie 3. niniejszych rozważań, a dotyczącą statusu inny/indziej w konkatenacjach z rozpatrywanymi seriami zaimków. Sądzę, że również w wypadku opozycji -ś: Ø mamy w interesującej nas grupie wyrażeń do czynienia z efektem zmiany o charakterze operacyjnym, a nie z zaimkowymi jednostkami leksykalnymi, z których każdy, niezależnie od pozostałych, powinien być odnotowywany w słowniku. Takie podejście jest powszechnie praktykowane w opisach języka polskiego. Problem ten wymagałby głębszego prześwietlenia. $\mathrm{W}$ tej chwili byłabym gotowa sformułować dwa podstawowe pytania badawcze: a) jak się te dwie zmiany (formy zaimkowe z inny/indziej vs. formy pozbawione tego ciągu, zaimki z -ś vs. zaimki bez -ś) mają do siebie nawzajem i b) w wypadku drugiego z tych przeciwstawień - która klasa stanowi tu operandy, a która produkty, innymi słowy, czy operacja miałaby polegać na ucięciu -ś, czy też raczej na jego dodaniu? Te dwa pytania pozostawiam w tym miejscu bez odpowiedzi, bo jest to temat na odrębne opracowanie, zasługujące na to, by stać się częścią szeroko zakrojonego projektu, który można byłoby zatytułować ogólnie: Polska gramatyka operacyjna.

\section{Źródła}

EJO: K. Polański (red.), Encyklopedia językoznawstwa ogólnego, Wrocław - Warszawa - Kraków 1993 [hasła poświęcone zaimkom w opracowaniu S. Karolaka].

ISJP: M. Bańko (red.), Inny słownik jezzka polskiego, t. I-II, Warszawa 2000.

NKJP: Narodowy Korpus Języka Polskiego, [on-line:] nkjp.pl.

WSJP PAN: P. Żmigrodzki (red.), Wielki słownik języka polskiego PAN, [on-line:] wsjp.pl. 


\section{Literatura}

ANDrejewicz U., 1989, O słowach zakończonych czastkami -ś, -kolwiek, -śkolwiek, -̇̇, -że i-żkolwiek - uwagi słownikowe, [w:] Z. Saloni (red.), Studia z polskiej leksykografii współczesnej, t. 3, Białystok, s. 219-234.

BogusŁAWski A., 1973, Właściwości pragmatyczne wyrażeń równoznacznych: projekt schematu, „Pamiętnik Literacki” LXIV, s. 121-151.

BogusŁAwsKi A., 1978, Towards an operational grammar, „Studia Semiotyczne” VIII, s. 2990; pol. przekład: Preliminaria gramatyki operacyjnej, tłum. R. Gozdawa-Gołębiowski, „Polonica” XIII, 1998, s. 163-223.

BogusŁaWski A., 1998, The semantic primitives 'someone', 'something' and the Russian contradistinction нибудь vs. -то, [w:] M. Grochowski, G. Hentschel (red.), Funktionswörter im Polnischen, Oldenburg, s. 33-53.

BogusŁawski A., 2013, Only from one. A particle in service of calling hearer's attention to one marked member of the contextually relevant alternative, [w:] K. Bochmann, A. Steube (red.), Sprache, Sprachvergleich, Sprachträger. Rudolf Růžička zum 9o. Geburstag von Freunden, wisenschaftlichen Weggefährten und Schülern, Leipzig, s. 17-56.

BogusŁawski A., 2018, Do kwestii „stałych lingwistycznych”. Czy „stała interpretacyjna” 'wiesz, o czym mówię??, „Linguistica Copernicana” 15, s. 27-36, [on-line:] http://dx.doi. org/10.12775/LinCop.2018.003.

BogusŁawski A., 2021, Lingwistyczna teoria mowy. Preliminaria, Warszawa.

Danielewiczowa M., 2007, Przymiotniki nieprzymiotniki (O pewnym niezwykłym typie wyrażeń w języku polskim), „Zbornik Matice srpske za slavistiku” 71-72, s. 223-236.

DANiElewiczowa M., 2012, W głąb specjalizacji znaczeń. Przysłówkowe metapredykaty atestacyjne, Warszawa.

Haspelmath M., 1997, Indefinite Pronouns, „Oxford Studies in Typology and Linguistics Theory", Oxford.

MańCZAK W., 2017, Polski słownik etymologiczny, Kraków.

ReJZeK J., 2015, Český etymologický slovnik, Praha.

SzCzePAnKowska I., 2012, O semantyce zaimków, „Białostockie Archiwum Językowe” nr 12, s. 275-292, [on-line:] https://repozytorium.uwb.edu.pl/jspui/bitstream/11320/1055/1/ BAJ_12_Szczepankowska.pdf.

Wierzbicka-Piotrowska E., 2011, Polskie zaimki nieokreślone: wybrane zagadnienia semantyczne, syntaktyczne i pragmatyczne, Warszawa.

Wittgenstein L., 2006, Tractatus logico-philosophicus, przeł. i wstęp B. Wolniewicz, Warszawa.

ZagóRska Brooks M., 1975, Polish Reference Grammar, The Hague - Paris.

ŻABowska M., 2017, Zaimki nieokreślone a modalne treści zdania, [w:] M. Danielewiczowa, K. Doboszyńska-Markiewicz, A. Wójcicka (red.), Nieokreśloność i granice, „Prace Językoznawcze Instytutu Filologii Polskiej UKSW”, t. 9, Warszawa, s. 237255, [on-line:] https://www.researchgate.net/publication/323105609_Zaimki_nieokreslo ne_a_modalne_tresci_zdania/link/5a7f3aagaca272a7376820aa/download. 


\section{Coś innego (Something Else) Is Different than co innego (Something Different). These and Similar Issues \\ Summary}

The article discusses the opposition between Polish pronouns ending with -ś and corresponding pronouns which lack this exponent. Such an opposition can be noticed in the combinations of units of both types with the expressions: inny/indziej (else/other), (e.g. ktoś inny : kto inny, coś innego : co innego, gdzieś indziej : gdzie indziej, kiedyś indziej : kiedy indziej, etc.), as well as in some modal contexts (e.g. Potrzebuję kogoś do pomocy vs. Potrzebuję kogo do pomocy, i. e. 'I need someone to help me'). The author of the article claims that pronouns in such pairs do not possess the same meaning, as they differ semantically and, in some cases, also pragmatically. The semantic difference between them comes down to the key contrast between the subject being spoken of and what is said about the subject. In the contexts under consideration, the pronouns ending with -ś are indexes used to denote objects in the world, while those belonging to the other type only pretend to occupy the positions of the predicate arguments, which are neither specified nor implemented. The article also considers the possibility of treating the analyzed types of expressions not as sets of separate lexemes, but rather as products of adequate operations that should be properly described. 